\section{How Has a Discussion of Županov's Work Highlighted Divisions in (Croatian) Sociology?}

Kako je rasprava o
Županovljevu radu
istaknula podjele u
(hrvatskoj) sociologiji?

\author{
Karin DOOLAN \\ Odjel za sociologiju, Sveučilište u Zadru, Hrvatska / \\ Department of Sociology, University of Zadar, Croatia \\ kdoolan@unizd.hr
}

In his 2004 presidential address to the American Sociological Association, Michael Burawoy (2005) discussed "the division of sociological labour" among professional, policy, public and critical sociologies. He also mentioned divisions between positivist and interpretive methodologies in sociology, quantitative and qualitative techniques, as well as micro and macro sociology. Similarly, in her review of the field of sociology over the past four decades, Rosemary Crompton (2008) mentioned well-known conceptual binaries such as fact-value, agencystructure and culture-economy, noting that the "paradigm wars" of the 1970s and 1980s, which marked the culmination of these divisions, continue to haunt sociological thought. It is this notion of "binaries", "divisions" or "paired oppositions" (Bourdieu, 1988) that I take up as an organising principle for my response to a discussion on the work of Josip Županov, a Croatian sociologist and political scientist, which took place in November 2015, co-organised by two Croatian Sociological Association's sections
Godine 2004., u predsjedničkom obraćanju Američkome sociološkom udruženju, Michael Burawoy (2005) govorio je o »podjeli sociološkoga rada« između profesionalne, javnopolitičke (policy), javne i kritičke sociologije. Spomenuo je i podjele između pozitivističkih $\mathrm{i}$ interpretativnih pristupa u sociologiji, kvantitativnih i kvalitativnih metoda, te mikrosociologije i makrosociologije. Slično tomu, Rosemary Crompton (2008) u osvrtu na znanstveno polje sociologije u posljednja četiri desetljeća, spominje dobro poznate konceptualne binarne opozicije, primjerice odnos činjenica i vrijednosti, strukture i djelovanja te kulture i ekonomije, primijetivši kako »ratovi paradigmi« vođeni sedamdesetih i osamdesetih godina 20. stoljeća, koji su označili vrhunac tih podjela, nastavljaju obilježavati sociološku misao. Upravo pojmove »binarna opozicija«, »podjela« ili »uparene suprotnosti« (Bourdieu, 1988) uzimam kao organizacijsko načelo svojeg osvrta na raspravu o radu Josipa Županova, hrvatskog sociologa i politologa, koja se održala u studenome 2015., u organizaciji dviju 
- Theoretical Sociology and Society, Economy, Work - and the Sociology department of Matica hrvatska, a non-profit organisation. Importantly, my response is not a summary of the main points discussed, although I outline the context for the reader who is not familiar with the debate. Rather, I use two moments in the discussion as a springboard to reflect on persisting divisions between theory and empirical study and value-laden and value-free research in (Croatian) sociology, albeit such reflections are well-trodden ground in sociology.

First, a brief note on the November event. It was inspired by a controversial article entitled "Josip Županov's egalitarian syndrome: a reappraisal" which was written by Danijela Dolenec from the University of Zagreb's Faculty of Political Science and published in the journal Politička misao (Croatian Political Science Review) in the fourth issue of 2014. My characterisation of it as controversial stems from the article's intention and subsequent reactions to it. The article's intention was stated as three-fold: to question the empirical foundations of Županov's concept of the "egalitarian syndrome", to question the framing of his liberal critique of socialism during the 1960s and 1970s as a unique voice of dissent at the time, and to question his diagnosis of Yugoslavia as insufficiently "modernised" with a capitalist understanding of modernisation as a yardstick for this diagnosis. In other words, Dolenec provided a critical reading of certain aspects of Županov's work, a controversial undertaking since Županov has largely enjoyed uncritical devotion in Croatian sociology. The article caused quite a stir in the sociological community and beyond, mostly con- sekcija Hrvatskoga sociološkog društva - Sekcije za teorijsku sociologiju i sekcije Društvo, ekonomija, rad - i Sociološkoga odjela Matice hrvatske. Bitno je naglasiti da moj osvrt nije sažetak glavnih točaka o kojima se raspravljalo, premda za čitatelja koji nije upoznat $\mathrm{s}$ tom raspravom njezin kontekst izlažem u osnovnim crtama. Zapravo, uzimam dva momenta iz rasprave kao početnu točku za promišljanje o podjelama između teorijskih i empirijskih pristupa te vrijednosno obilježenih i vrijednosno neutralnih istraživanja u (hrvatskoj) sociologiji, premda takva promišljanja u sociologiji nisu novost.

Najprije, jedna kratka bilješka u vezi sa skupom iz studenoga. Potaknut je kontroverznim člankom naslovljenim »Preispitivanje 'egalitarnog sindroma' Josipa Županova«, koji je napisala Danijela Dolenec s Fakulteta političkih znanosti Sveučilišta u Zagrebu i koji je objavljen u četvrtom broju časopisa Politička misao iz 2014. Članak sam opisala kao kontroverzan, kako zbog njegovih ciljeva, tako i zbog reakcija koje su uslijedile nakon njegova objavljivanja. U članku se navodi da je pisan s trima ciljevima: preispitati empirijska uporišta Županovljeva koncepta »egalitarnog sindroma«, preispitati prikazivanje njegove liberalne kritike socijalizma šezdesetih i sedamdesetih godina 20. stoljeća kao jedinstvenoga glasa neslaganja u to doba te, naposljetku, preispitati tezu o Jugoslaviji kao nedovoljno »moderniziranoj«, pri čemu je kao mjerilo prilikom donošenja te dijagnoze uzeto kapitalističko shvaćanje modernizacije. Kritičko čitanje određenih vidova Županovljeva rada, kako to čini Danijela Dolenec, prijeporan je pothvat, zato što Josip Županov u hrvatskoj sociologiji uglavnom uživa nekritičnu odanost. Članak je izazvao popriličnu pomutnju 
sisting of attempts to defend Županov's legacy. The format of the November event was as follows: Dolenec presented her main arguments, two respondents - Mirko Petrić from the University of Zadar's Department of Sociology and Duško Sekulić from the University of Zagreb's Faculty of Law - shared their comments to her article and then the floor was opened to comments from the audience. The discussion mainly focussed on the validity of the concept of the "egalitarian syndrome". I wish to reflect on two criticisms made of Dolenec's article at the event which I see as indicative of broader tensions regarding how sociology should be "done". The first one is that she fetishises the importance of empirical foundations for theoretical points; the second is that her critique of Županov's work is valueladen. More specifically, her appraisal of Županov's work was disqualified as being "leftist". Both of these criticisms illustrate ways of "doing" sociology and I wish to engage with them by pointing out well-established alternatives, largely from a Bourdieuean perspective. Importantly, I do not see either of these critiques of Dolenec's analysis as valid.

\section{The problematic dualism between theory and empirical research}

Dolenec has accused Županov of methodological sloppiness. She argues that the small-scale research study that empirically grounded his "egalitarian syndrome" concept is insufficiently rigorous. In particular, she aims her critique at the construct validity of the study's questionnaire (questioning whether it indeed measured what it set out to measure), as well as Županov's interpretation u sociološkoj zajednici i izvan nje, a ta se pomutnja uglavnom sastojala od pokušaja da se obrani naslijeđe Josipa Županova. Na skupu u studenom Danijela Dolenec iznijela je glavne argumente svog rada, nakon čega su Mirko Petrić s Odjela za sociologiju Sveučilišta u Zadru i Duško Sekulić s Pravnoga fakulteta Sveučilišta u Zagrebu, podijelili svoje viđenje njezina članka te je rasprava otvorena za pitanja iz publike. Rasprava je uglavnom bila usredotočena na valjanost pojma »egalitarni sindrom«. Željela bih se osvrnuti na dvije kritike izrečene na skupu na račun članka Danijele Dolenec, koje smatram dobrim pokazateljem tenzija u vezi s tim kako bi se sociologijom trebalo »baviti«. Prva je da fetišizira važnost empirijske utemeljenosti teorijskih tvrdnji; druga da je njezina kritika Županovljeva djela vrijednosno obilježena. Da budem preciznija, njezina procjena Županovljeva djela osporena je kao »ljevičarska«. Obje kritike primjer su različitih načina na koje se »bavi« sociologijom i želim im pristupiti isticanjem etabliranih alternativa, velikim dijelom iz bourdieuovske perspektive. Bitno je istaknuti da nijednu od tih dviju kritika ne doživljavam kao opravdanu kritiku analize koju je provela Dolenec.

\section{Problematična dvojnost izme- đu teorije $i$ empirijskog istra- živanja}

Dolenec je Županovu zamjerila metodološku površnost. Tvrdi da istraživanje na kojemu se empirijski temelji njegov koncept »egalitarnog sindroma«, a koje je provedeno na malom uzorku, nije dovoljno znanstveno rigorozno. Osobito je kritična prema konstruktnoj valjanosti ankete koja je provedena unutar tog istraživanja (mjere li čestice $\mathrm{u}$ anketi ono što bi trebale mjeriti), kao i pre- 
of the results and problematic generalisation (from a sample of workers in a Croatian industrial city to the population of Yugoslavia). One of the responses to this critique at the November event was that a theoretical point can have value without being substantiated by data. The work of German sociologist Ulrich Beck could serve to exemplify this. According to a recent, rather unkind assessment of Beck's approach by S. Pryke, "while it would be inaccurate to say that Beck has nothing interesting to say about, among other things, the nature of risk in contemporary society, it is difficult to find evidence of how research figures in his thinking. His books rather give the impression that he has simply sat down and written about society through the medium of pre-existing theory" (Pryke, 2013: 78). Adapting the argument about the self-sufficiency of theory more specifically to the case of Županov's work, his concept of "the egalitarian syndrome", a "condition" which he claimed people in Yugoslavia and then later in Croatia suffered from, ${ }^{1}$ can be taken as reflecting social reality without requiring empirical data as proof. Dolenec's comment to this was spot on: Županov himself aspired to

\footnotetext{
${ }^{1}$ Županov claimed that people in Yugoslavia before the 1990s and then in Croatia after the 1990s had/have radically egalitarian values which negatively shape professional aspirations and consequently impede broader economic development and "modernisation": "Radical egalitarianism is dysfunctional not just for the development of industrialism, as I was proving more than thirty years ago, but it is also dysfunctional for the development of the market economy as such. Radical egalitarianism is a big barrier to the modernisation of Croatian society" (Županov, 2011 [1995]: 161).
}

ma Županovljevu tumačenju rezultata istraživanja i neopravdanim generalizacijama (od uzorka radnika u jednom hrvatskom industrijskom gradu do stanovništva Jugoslavije). Na skupu u studenom, jedna od reakcija na tu kritiku bila je da neka teorijska tvrdnja može imati težinu i bez empirijske osnove. Kao primjer toga može se uzeti rad njemačkoga sociologa Ulricha Becka. Prema nedavnoj S. Prykeovoj neljubaznoj ocjeni Beckova pristupa, "premda bi bilo nepravedno reći da nema ničeg zanimljivog u Beckovu pisanju, između ostalog, o prirodi rizika u suvremenome društvu, teško je pronaći dokaze tomu kakvu ulogu istraživanje ima u njegovu razmišljanju. Prije bi se moglo reći da njegove knjige odaju dojam da je jednostavno sjeo i pisao o društvu kroz medij već postojeće teorije « (Pryke, 2013: 78). Primijeni li se tvrdnja o samodostatnosti teorije na konkretni primjer Županovljeva djela i rada, rekli bismo da njegov koncept »egalitarnog sindroma«, »stanja« od kojeg je tvrdio da boluju stanovnici, najprije Jugoslavije, a poslije Hrvatske, ${ }^{1}$ odražava društvenu stvarnost, bez potrebe za empirijskim podacima kojima bi se to poduprlo. Komentar Danijele Dolenec na tu tvrdnju

${ }^{1}$ Županov je tvrdio da su stanovnici Jugoslavije prije devedesetih godina 20 . stoljeća, a potom i Hrvatske od devedesetih godina 20. stoljeća, imali, odnosno još uvijek imaju, radikalno egalitarističke vrijednosti, koje negativno oblikuju profesionalne težnje te, posljedično, priječe širi gospodarski razvoj i »modernizaciju«: »Radikalni je egalitarizam veoma disfunkcionalan ne samo za razvoj industrijalizma, kako sam dokazivao još prije više od trideset godina, nego je disfunkcionalan za razvoj tržišne ekonomije uopće. Radikalni egalitarizam velika je zapreka modernizaciji hrvatskog društva« (Županov, 2011 [1995]: 161). 
an empirical grounding of his theoretical claims and his work should be evaluated accordingly. In other words, the critique about Dolenec fetishising the importance of empirical foundations for theoretical points is unfounded. Her critique is contextual: she attempts to do justice to Županov's own intention.

Nonetheless, this critique raises a broader issue of the importance of empirical substantiation of theoretical claims in sociology. Durkheim's position on this was clear: the founding of sociology was premised on the importance of empirical data. Ritzer (1998) made the point that E. Durkheim had criticised A. Comte and H. Spencer for "abstract" theorising worrying that this risked sociology becoming a branch of philosophy. In more recent times, P. Bourdieu's intellectual project has been to overcome the "division of labour" in sociology between those who "do" theory and those who "do" research. Bourdieu was critical not only of "theoretical theory", which he defined as "a prophetic or programmatic discourse that is its own end" (Bourdieu, 1988: 774), but also of "empiricist methodology" which, as he put it, requires preliminary definitions of concepts "which automatically produce a closure effect" (Bourdieu, 1988: 774). Bourdieu borrowed Kant's dictum to illustrate his own position: "Theory without empirical research is empty, empirical research without theory is blind" (Bourdieu, 1988: 774-775). The comment about Dolenec fetishising the importance of empirical foundations for theoretical points reinforces the duality between theory and empirical research which structures social thought and which Bourdieu and many others have productively sought to overcome. bio je na mjestu: sâm Županov težio je empirijskome utemeljenju svojih teorijskih tvrdnji, i u skladu s time trebalo bi procjenjivati i njegov rad. Drugim riječima, kritika da Danijela Dolenec fetišizira važnost empirijske utemeljenosti teorijskih tvrdnji, neosnovana je. Njezina je kritika kontekstualna i njome se nastoji pravedno odnositi prema $\check{Z} \mathrm{u}$ panovljevoj vlastitoj namjeri.

Bez obzira na to, ta kritika postavlja šire pitanje važnosti empirijskoga potkrepljivanja teorijskih tvrdnji u sociologiji. Durkheimov stav o tome bio je jasan: utemeljenje sociologije zasnivalo se na važnosti empirijskih podataka. Ritzer (1998) ističe kako je E. Durkheim kritizirao A. Comtea i H. Spencera zbog »apstraktnoga « teoretiziranja, zabrinut da bi zbog toga sociologija mogla postati granom filozofije. $\mathrm{U}$ novije vrijeme, Bourdieuov intelektualni projekt bio je nadići »podjelu rada« u sociologiji između onih koji se »bave« teorijom i onih koji se »bave« istraživanjem. Bourdieu je kritičan i prema »teorijskoj teoriji«, koju definira kao »proročki ili programski diskurs koji je samome sebi svrhom « (Bourdieu, 1988: 774), ali i prema »empirističkoj metodologiji« koja, kako on to kaže, zahtijeva preliminarne definicije koncepata »koji automatski stvaraju zatvorenost« (Bourdieu, 1988: 774). Da bi objasnio vlastito gledište, Bourdieu posuđuje Kantovu tvrdnju: »Teorija bez empirijskog istraživanja je prazna, empirijsko istraživanje bez teorije slijepo« (Bourdieu, 1988: 774-775). Primjedba da Danijela Dolenec fetišizira važnost empirijske utemeljenosti teorijskih tvrdnji pojačava tu dvojnost između teorije i empirijskog istraživanja, koja strukturira društvenu misao, i koju su Bourdieu i mnogi drugi uspješno nastojali nadvladati. 


\section{The (im)possibility of value- free analysis}

The dismissal of Dolenec's analysis of Županov's work as "leftist" brings into focus another much discussed divide between "objective scientific" and "politically subjective" analyses. Since at the November event this critique came from a sociologist, it implies that there is such a thing as value-free analysis in sociology. Although one would think that the subjectivity-objectivity debate is well-covered ground in the relevant literature, Letherby, Scott and Williams (2013) have just recently published a book entitled Objectivity and Subjectivity in Social Research, with a focus on these debates in sociology, illustrating the persistence of this dualism beyond Croatian borders.

For Black (2013), for instance, sociology should and can be free from value judgements and he claimed to take inspiration from $\mathrm{M}$. Weber in that matter. In specifying what he means by value-free social science, Black distinguished between "external" value judgements (such as whether a particular public policy is good or bad, just or unjust, or whether a particular reform is desirable or undesirable) and "internal" value judgements (such as whether colleagues have used proper research methods in their work and whether their evidence justifies their conclusions), concluding that social scientists should only make "internal" value judgements. As a sociologist committed to social justice, I find his distinction problematic: by insisting that sociologists should only make "internal" value judgements, Black dismissed a whole rich field of sociological thought drawing on critical approaches such as feminism, Marxism

\section{(Ne)mogućnost vrijednosno neutralne analize}

Diskvalificiranje analize Županovljeva rada koju je napravila Danijela Dolenec kao »ljevičarske«, u žarište dovodi još jednu podjelu o kojoj se mnogo raspravlja, onu između »objektivno znanstvene« i »politički subjektivne« analize. Budući da je ta izjava na skupu došla od jednoga sociologa, ona podrazumijeva da $\mathrm{u}$ sociologiji postoji vrijednosno neutralna analiza. Premda bi se moglo pomisliti da je rasprava o subjektivnosti i objektivnosti dobro obrađena u relevantnoj literaturi, Letherby, Scott i Williams (2013) nedavno su objavili knjigu naslova $\mathrm{Ob}$ jectivity and Subjectivity in Social Research (Objektivnost $i$ subjektivnost $u$ društvenim istraživanjima), u kojoj se bave takvim raspravama u sociologiji, što zorno oslikava trajnost tog dualizma i izvan hrvatskih granica.

Primjerice, Black (2013) smatra da bi sociologija trebala biti i da može biti slobodna od vrijednosno obilježenih sudova i tvrdi da mu je M. Weber poticaj u takvome razmišljanju. Objašnjavajući što točno podrazumijeva pod pojmom vrijednosno neutralne društvene znanosti, Black razlikuje »vanjske« vrijednosne sudove (poput toga je li neka javna politika dobra ili loša, pravedna ili nepravedna ili je li neka određena reforma poželjna ili nepoželjna) i »unutarnje« vrijednosne sudove (poput toga jesu li se kolege $u$ svojem radu koristili pravilnim metodama istraživanja $\mathrm{i}$ opravdavaju li njihovi dokazi njihove zaključke) te zaključuje da bi sociolozi trebali donositi samo »unutarnje« vrijednosne sudove. Kao sociologinja posvećena društvenoj pravdi, smatram tu distinkciju dvojbenom: ustrajući na tome da bi sociolozi trebali donositi samo »unutarnje« vrijednosne sudove, Black odbacuje cijelo jedno bo- 
or post-colonialism which have an explicit normative agenda. In addition, his distinction is unhelpful for situating, for example, a feminist critique of positivist methodology. Is the criticism about the quantitative data reported in a study not doing justice to the voices of oppressed women an "external" or "internal" value judgement?

In stark opposition to Black, Bourdieu (1988) was suspicious of sociologists who claim that their research is politically disinterested. For Bourdieu, to achieve scientific legitimacy, researchers need to acknowledge their positionality rather than claim neutrality; they need to be explicitly "reflexive". K. Maton noted that most discussions of reflexivity "share versions of a basic argument that authors should explicitly position themselves in relation to their objects of study so that one may assess researchers' knowledge claims in terms of situated aspects of their social selves and reveal their (often hidden) doxic values and assumptions" (Maton, 2003: 54). For Bourdieu (Bourdieu and Wacquant, 1992), there are three types of biases that may blur the "sociological gaze": social origins and coordinates of the individual researcher, his or her position in the academic field and his or her intellectual bias. Bourdieu (2007 [2002]) skilfully illustrated the principle of reflexivity by reflecting on his biases in Sketch for a Self-Analysis where he interpreted his own professional trajectory.

Dolenec's response to the dismissal of her analysis as "leftist" focussed on what Black (2013) would call "internal" value judgements. Her point was straightforward: irrespective of her political convictions, the fact remains that gato područje sociološke misli koje ideje crpi iz kritičkih pristupa poput feminizma, marksizma ili postkolonijalizma, a koji imaju nedvosmisleno normativan program. Usto, takva distinkcija nije od koristi za smještanje u okvire, primjerice, feminističke kritike pozitivističke metodologije. Je li kritika da kvantitativni podatci objavljeni u nekoj studiji nisu pravi prikaz glasova potlačenih žena »vanjski« ili »unutarnji« vrijednosni sud?

U oštroj suprotnosti s Blackom, Bourdieu (1988) je sumnjičav prema sociolozima koji tvrde da je njihovo istraživanje politički nepristrano. Za Bourdieua, da bi postigli znanstveni legitimitet, istraživači trebaju priznati svoju pozicionalnost, a ne tvrditi da su neutralni; oni trebaju biti eksplicitno »refleksivni«. K. Maton primjećuje kako su većini rasprava o refleksivnosti »zajedničke različite inačice osnovne tvrdnje da bi se autori trebali jasno postaviti u odnosu na svoj predmet istraživanja, kako bi čitatelj mogao procijeniti istraživačeve tvrdnje $\mathrm{u}$ odnosu na aspekte njihova društvenog sebstva i otkriti njihove (često skrivene) vrijednosne sudove i pretpostavke« (Maton, 2003: 54). Za Bourdieua (Bourdieu i Wacquant, 1992) postoje tri tipa predrasuda koje mogu zamutiti »sociološki pogled《: društveno podrijetlo i »koordinate« istraživača, njegov ili njezin položaj u akademskome području i njegove ili njezine intelektualne predrasude. Bourdieu (2007 [2002]) vješto ocrtava načelo refleksivnosti, promišljajući vlastite predrasude u djelu Sketch for a Self-Analysis (Nacrt za samoanalizu), u kojemu tumači vlastiti profesionalni put.

Odgovarajući na obezvređivanje njezine analize kao »ljevičarske«, Danijela Dolenec usredotočila se na ono što bi Black (2013) nazvao »unutarnjim« vrijednosnim sudovima. Njezin je odgovor bio jasan: bez obzira na njezino politič- 
Županov's concept of the "egalitarian syndrome" was not based on data obtained in a methodologically rigorous manner. A. Štulhofer and I. Burić, who have attempted to defend Županov's concept in their article "Is the egalitarian syndrome a mere theoretical fantasy? An empirical hommage to Josip Županov", agreed with her, stating that the concept had indeed "never undergone serious empirical verification" (Štulhofer and Burić, 2015: 10). However, even in its value-ladeness, Dolenec's critique has legitimacy. Although in certain sociological circles, such as those whose voices were most loudly heard at the November event, her analysis is dismissed for being value-laden, from a critical sociological perspective, as advocated by Bourdieu, this approach does not disqualify her argument. As Maton (2003) has observed, and I would argue, researchers can and do have both social and intellectual interests. There is no necessary contradiction between the leftist political commitment that may have led Dolenec to revisit Županov's work and the intellectual attempt to assess Županov's work in an "objective", balanced manner.

I expect the debate on Županov's work to continue. To the extent that it does, I hope that Dolenec's respondents will refrain from reinforcing the tired binaries that continue to structure (Croatian) sociology. I also hope that critical sociological research will have more to say about these debates in Croatia. As Burawoy (2005) has noted, critical sociology makes professional sociology aware of its biases and silences. Županov's followers who have criticised Dolenec's "leftist" critique have their own biases (just as Županov himself ko uvjerenje, ostaje činjenica da Županovljev koncept »egalitarnog sindroma« nije utemeljen na podatcima dobivenim rigoroznom metodološkom provjerom. A. Štulhofer i I. Burić, koji su pokušali obraniti Županovljev koncept u članku »Je li egalitarni sindrom samo teorijska fantazija? Empirijski hommage Josipu Županovu«, slažu se s njom, izjavivši da taj koncept zaista nikada prije nije bio »podvrgnut ozbiljnoj empirijskoj provjeri« (Štulhofer i Burić, 2015: 10). No, kritika Danijele Dolenec vjerodostojna je čak i u svojoj vrijednosnoj obilježenosti. Premda je u određenim sociološkim krugovima, poput onih čiji su se glasovi najviše čuli na skupu u studenome, njezina analiza upitna zbog toga što je vrijednosno obilježena, iz perspektive kritičke sociologije, kakvu zagovara Bourdieu, takav pristup ne obezvređuje njezine zaključke. Kao što je Maton (2003) primijetio, a s čime se ja slažem, istraživači mogu imati, i imaju, kako društvene, tako $\mathrm{i}$ intelektualne interese. Ne mora nužno postojati tenzija između lijevoga političkog opredjeljenja, koje je Danijelu Dolenec možda navelo da ponudi novu ocjenu Županovljeva rada, i intelektualnog pokušaja da to učini na »objektivan« način.

Očekujem da će se rasprava o djelu Josipa Županova nastaviti. Bude li tako, nadam se da će se oponenti Danijele Dolenec suzdržati od inzistiranja na istrošenim binarnim opozicijama koje još uvijek obilježavaju (hrvatsku) sociologiju. Nadam se i da će kritička sociologija imati još što dodati tim raspravama u Hrvatskoj. Kao što je Burawoy (2005) primijetio, kritička sociologija omogućuje profesionalnoj sociologiji da postane svjesna svojih predrasuda i tišina. Županovljevi sljedbenici koji su kritizirali »ljevičarsku« kritiku Danijele Dolenec, imaju vlastite predrasude (kao i sam $\breve{Z}$ panov). Moguće je da neke od tih predra- 
had). Some of these biases, which demand acknowledgement and reflection, could stem from their socialisation as sociologists in Croatia during the late 1980s and 1990s. During this time, Croatian sociology arguably distanced itself from "value-laden" research since that was seen as the legacy of Marxist sociology. The disappearance of Marxist class analysis illustrates this point. This distancing can be interpreted as a means to achieve scientific legitimacy, but it was equally the outcome of a political process in its own right. At the time, this focus seemed to offer new horizons for Croatian sociology, but in the decades since, it has become a conservative status quo which needs to be scrutinised.

\section{LITERATURA / REFERENCES}

Black, Donald (2013). »On the almost inconceivable misunderstandings concerning the subject of value-free social science«, The British Journal of Sociology, 64 (4): 763-780. doi: 10.1111/1468-4446.12034

Bourdieu, Pierre (1988). „Vive la Crise!: For Heterodoxy in Social Science«, Theory and Society, 17 (5): 773-787.

Bourdieu, Pierre (2007 [2002]). Sketch for a Self-Analysis. Cambridge: Polity Press.

Bourdieu, Pierre i Wacquant, Loïc (1992). Invitation to Reflexive Sociology. Cambridge: Polity Press.

Burawoy, Michael (2005). »For Public Sociology«, American Sociological Review, 70 (1): 4-28. doi: 10.1177/000312240507000102

Crompton, Rosemary (2008). »Forty Years of Sociology: Some Comments«, suda, koje je potrebno priznati i o njima promišljati, proizlaze iz njihova sociološkog sazrijevanja u Hrvatskoj kasnih osamdesetih i tijekom devedesetih godina 20. stoljeća. U tom se razdoblju hrvatska sociologija nedvojbeno udaljila od »vrijednosno obilježenoga« istraživačkog rada, zato što se to smatralo naslijeđem marksističke sociologije. Tu tvrdnju zorno oslikava nestanak marksističke klasne analize. To bi se udaljavanje moglo protumačiti kao sredstvo kojim se postiže znanstveni legitimitet, ali jednako je tako ishod političkoga procesa samog po sebi. Tada se činilo da takvo udaljavanje otvara nove obzore za hrvatsku sociologiju, ali u desetljećima koja su uslijedila, ono je postalo konzervativnim statusom quo koji treba preispitati.

Sociology, 42 (6): 1218-1227. doi: 10.1177/0038038508096942

Dolenec, Danijela (2014). »Preispitivanje 'egalitarnog sindroma' Josipa Županova / Josip Županov's Egalitarian Syndrome: A Reappraisal«, Politička misao, 51 (4): 41-64.

Letherby, Gayle, Scott, John i Williams, Malcolm (2013). Objectivity and Subjectivity in Social Research. London: Sage.

Maton, Karl (2003). »Reflexivity, Relationism \& Research. Pierre Bourdieu and the Epistemic Conditions of Social Scientific Knowledge«, Space and Culture, 6 (1): 52-65. doi: $10.1177 / 1206331202238962$

Pryke, Sam (2013). »The nature of social theory«, u: Ian Marsh (ur.). Theory and Practice in Sociology. New York: Routledge, str. 73-91.

Ritzer, George (1998). »Emile Durkheim«, u: Murray E. G. Smith (ur.). Early Modern Social Theory: Se- 
lected Interpretive Readings. Toronto: Canadian Scholar's Press, str. 110-149.

Štulhofer, Aleksandar i Burić, Ivan (2015). »Je li egalitarni sindrom samo teorijska fantazija? Empirijski hommage Josipu Županovu / Is the egalitarian syndrome a mere theore- tical fantasy? An empirical hommage to Josip Županov«, Politička misao, 52 (3): 7-31.

Županov, Josip (2011 [1995]). »Hrvatsko društvo danas - kontinuitet i promjena / Croatian society today Continuity and change «, Politička misao, 48 (3): 145-163. 